\title{
Research Libraries in Germany
}

\author{
Dr. Scheliha is cataloger, Bryn Mawr \\ College Library.
}

$\mathrm{G}$

ERMAN RESEARCH libraries are beginT ning to recover from the various blows they have had to endure since 1933. The first of these was not launched by allied bombs, but by the Nazi regime whichsoon after it came into power-ordered many valuable books to be cast into the flames either because their authors or their contents were not in accord with the new doctrine founded on nationalism and prejudice. At the same time the shelves of even the most scholarly libraries were filled with unscientific or pseudo-scientific books written for the purposes of Nazi propaganda. Research libraries, as well as research itself, were enlisted to aid in the general preparations for the war. In 1937 "Book Week" was celebrated first in Weimar and then in Essen, "the foundry of the German Reich," so that, in the words of the speaker on this festive occasion, the national mind would learn to connect the book with the sword. ${ }^{1}$ But when the war brought the air raids to German towns, the sword turned against the book. Since the very beginning of the war, books had been evacuated to places which seemed bomb-proof: salt and potash mines and forest lodges. But even so, the research libraries suffered tremendous losses. Many of the books which had remained in them were destroyed along with the library buildings. Others were lost or stolen during removal, or ruined by mice and mould. All in all, eight million books, or 57 per

${ }^{1}$ Hederich, Karl Heinz. Nationalsozialismus und Buch. Mainz, Hanns Marxen, 1937. cent of the prewar holdings, were destroyed in 31 libraries. Many of these were rare books or precious collections which can never be replaced. Some libraries lost all their catalogs, some saved only a few special ones, but even where the catalogs are at hand, they are useless to all intents and purposes, since they no longer represent what is actually there. ${ }^{2}$

In the general chaos following the war, many libraries had to be closed for a time. But in spite of the lack of communication, the changes in the staff, and the difficult living conditions, the libraries soon began to reorganize. It will be several decades before the present holdings have been supplemented and the catalogs-such as they are-revised. Nobody knows whether or not the German libraries will ever be as rich in book collections as they were before 1933. But all the documents and reports relating to library work in Germany are eloquent of the amazing activity which the German libraries display in building up their collections again and bringing their catalogs up-to-date. New policies have been developed for the purchase of old and new books, for interlibrary loan, for exchange agreements with foreign libraries, and for making records of old and new material. Many librarians hope to replace part of their lost material by microfilms. Perhaps they will experiment to determine to what extent books may really be replaced in this way, and for what kind of material the microfilming is most useful.

${ }^{2}$ Leyh, Georg. Die deutschen wissenschaftlichen Bibliotheken nach dem Krieg. Tübingen, J. C. B. Mohr, 1947. Reviewed and summarized by Butler, Pierce. Library Quarterly, 18:120-123, April 1948. 
A number of libraries are trying to make their material available as quickly as possible by dint of selective cataloging. The University Library of Hamburg, for instance, fully catalogs only the most important material, while the less important is cataloged only briefly, and the unimportant simply listed. In the Public Research Library of Berlin (Oeffentliche Wissenschaftliche Bibliothek, the former Preussische Staatsbibliothek), only a skeleton of the new acquisitions is cataloged for the public catalog, while a number of catalogs on special material-biographies, periodicals, newspapers, etc.-are slowly being built up.

Some libraries resumed circulation as early as 1945, and now almost all research libraries are open to readers, ${ }^{3}$ some, of course, with certain restrictions, as they not only lack reading matter but also reading rooms. The University Library of Hamburg has even introduced the unknown practice of immediate delivery of books.

Scholarly library research has also begun again. Deutsche Nationalbibliographie, Deutsche Musikbibliographie, Bibliographie der Kunstblätter, Jahresverzeichnis des deutscen Schriftums, and Jahresverzeichnis der deutschen Muxikalia un Musikschriften -all these great bibliographical works which had been discontinued are again being published. The German library periodical, Zentralblatt für Bibliothekswesen, which reappeared in 1947 , stresses the task of again developing scholarly librarianship according to the old standards. It seems that the German librarians are courageously and energetically trying to reorganize the libraries and library work after the model of the prewar libraries. In the technical services, to be sure, improvements have been introduced and more will, perhaps, be made in the future. On the whole, the prewar policies

${ }^{3}$ The list in Leyh's book is already obsolete. In I948 the Deutsche Buecherei in Leipzig and the Staatsbibliothek in Munich were opened. See Leyh in the supplement to his book, Zentralblatt für Bibliothekswesen, 62:157, January-April 1948 . and tendencies are being resumed. Just as before the war they are concerned with the preservation of books and with making research material available to students and scholars, while the educational task of the library is all but forgotten. The only step in this direction seems to be the elimination of Nazi propaganda material. The outline for this task was given by the Allied Control Council, but the execution was handled differently in each zone. In the French zone the librarians alone were responsible for the elimination. In the Russian zone a long list has been worked out, so that the process of eliminating may be completed by clerical workers. In the American zone a shorter list was issued but soon withdrawn. There and in the British zone the librarians work together with the authorities of the military government. The amount of literature which had to be eliminated in this way may be seen from a report on the Saxon State Library (Saechsische Landesbibliothek) in Dresden. Fifteen thousand cards were removed from the subject catalog, I2 I cards relating to 56 persons were removed from the biographical catalog, 1200 cards were taken from the serials catalog, and 5600 volumes of monographs, 2000 volumes of serials, and r 400 volumes of newspapers were removed from the shelves. Some material, such as newspapers and military books published before 1913 , is preserved in two copies in the Deutsche Buecherei in Leipzig. In Hamburg and other libraries in the west zones the undesirable political and military material is marked and stored in a separate room. Those who wish to use it are admitted only by special permission. Even in medium-sized university libraries, 7000 to 10,000 volumes had to be eliminated. Some libraries were closed for months in order to complete the time-consuming task of elimination. But this step toward political responsibility should not be (Continued on page 394) 
same work, but in Greek. I was free to examine page after page. It so happened that this was the last book in the last library that I visited in Persia. Here in this most fanatical and out-of-the-way city in the Middle East, I was more at home for the moment than I had been in the whole trip. Imagination carried me back to the Morgan Library and I saw again the pages of their

\section{Dioscorides.}

If in this account there has been more of books than of libraries, it is due in part, at least, to the fact that except for Egypt a library is looked upon much less as an institution to disseminate information, than as an organization to collect and catalog books. These are to be used, yes, but above all to be preserved.

\section{Research Libraries in Germany}

\section{(Continued from page 380 )}

the last. Besides those books which prove to have been instruments of Nazi propaganda, there are many, by apparently nonpolitical authors which, when carefully examined, show the infiltration of Hitler's tenets. One of the most effective methods of the Nazi party was to camouflage propaganda in this way, and many authors either consciously or unconsciously helped in this campaign. ${ }^{4}$ It is impossible to destroy all these books, but they present a problem and even a danger as long as great parts of the German population still incline to nationalism and antisemitism. In the postwar publications of German librarians these problems have not been touched any more than other educational and political problems. This apparent oversight has its source in the tradition of German librarianship and the training of librarians. The fields covered in the United States by the duties of the "readers' adviser" are almost unknown in Germany.

\footnotetext{
${ }^{4}$ Lehmann-Haupt, Hellmut. "What the Nazis Did to Children's Books." The Horn Book Magazine, 25:220-230, May-June 1949.
}

Book selection and annotation, display of instructive and valuable books, and personal advice to readers are not to be found in the research libraries. This is all the more unfortunate since, in Germany, research libraries also fulfil the functions of public libraries. The so-called "volksbuechereien" are not the equivalent of public libraries and have only small book collections selected for uneducated readers. The gap between the professional librarian working in research libraries and the librarian of "volksbuechereien" who, indeed, performed some educational work, was always great and does not seem to have diminished. The professional librarian did not take into consideration that he too had educational tasks and that the adult reader needed his guidance. The reorganization of the libraries, so well performed in many respects, has not balanced this lack in German librarianship-a lack which may perhaps prove more disastrous for German culture than the loss of books. 